\section{What does corporate social advocacy signal? Evidence from boycott participation decisions}

Corporate social advocacy signal

\author{
University of Pretoria, Pretoria, South Africa, and \\ Imhotep P. Alagidede \\ University of The Witwatersrand, Johannesburg, South Africa
}

Pyemo N. Afego
Received 7 October 2020 Revised 26 November 2020 28 January 2021

Accepted 7 February 2021

\begin{abstract}
Purpose - This paper explores how a firm's public stand on a social-political issue can be a salient signal of the firm's values, identity and reputation. In particular, it investigates how boycott participation-conceptualized as a cue of a corporation's stand on important social-political issues-may affect the stock market valuation of that corporation, as well as how corporations legitimise their stand on the issues.

Design/methodology/approach - The authors employ a mixed-methods design that uses both qualitative techniques (content analysis) and quantitative methods (event study methodology) to examine a sample of US firms who participated in a boycott campaign that sought to call attention to issues of hate speech, misinformation and discriminatory content on social media platform Facebook.

Findings - Findings from the qualitative content analysis of company statements show that firms legitimise their stand on, and participation in, the boycott by expressing altruistic values and suggesting to stakeholders that their stand aligns not only with organizational values/convictions but also with the greater social good. Importantly, the event study results show that firms who publicly announced their intention to participate in the boycott, on average, earn a statistically significant positive abnormal stock return of $2.68 \%$ in the four days immediately after their announcements.

Research limitations/implications - Findings relate to a specific case of a boycott campaign. Also, the sample size is limited and restricted to US stocks. The signalling value of corporate social advocacy actions may vary across countries due to institutional and cultural differences. Market reaction may also be different for issues that are more charged than the ones examined in this study. Therefore, future research might investigate other markets, use larger sample sizes and consider a broader range of social-political issues.

Practical implications - The presence of significant stock price changes for firms that publicly announced their decision to side with activists on the issue of hate propaganda and misinformation offers potentially valuable insights on the timing of trades for investors and arbitrageurs. Insights from the study also provide a practical resource that can be used to inform organizations' decision-making about such issues.

Social implications - Taking the lead to push on social-political issues, such as hate propaganda, discrimination, among others, and communicating their stands in a way that speaks to their values and identity, could be rewarding for companies.

Originality/value - This study provides novel evidence on the impact that corporate stances on important social-political issues can have on stock market valuation of firms and therefore extends the existing related research which until now has focused on the impact on consumer purchasing intent and brand loyalty.
\end{abstract}

Keywords Abnormal return, Content analysis, Event study, Boycotts, Corporate social advocacy,

Signalling effect

Paper type Research paper

(C) Pyemo N. Afego and Imhotep P. Alagidede. Published in Journal of Capital Markets Studies. Published by Emerald Publishing Limited. This article is published under the Creative Commons Attribution (CC BY 4.0) license. Anyone may reproduce, distribute, translate and create derivative works of this article (for both commercial and non-commercial purposes), subject to full attribution to the original publication and authors. The full terms of this license may be seen at http://creativecommons.org/licences/by/4.0/ legalcode

The authors would like to thank two anonymous reviewers and Prof. Guler Aras (editor) for their many valuable comments and suggestions.

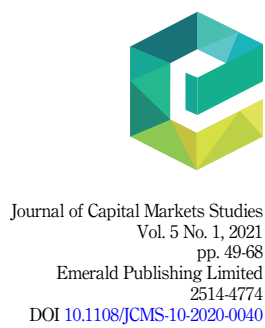



$\underset{5,1}{\mathrm{JCMS}}$

\section{Introduction}

Recent years have seen increased scholarly interest in corporate social advocacy (CSA)-i.e. a company's public stance on often contentious social-political issues (e.g. Coombs and Holladay, 2018; Dodd and Supa, 2014; Rim et al., 2020; Wettstein, and Baur, 2016). Despite this, however, several open questions remain: What are the motives for firms that engage with social-political issues and how do they negotiate their legitimacy to engage with such issues? Also, do these engagements signal a firm's reputation or organizational values which are then capitalized into its stock price?

In this study, we address the above questions by taking an interdisciplinary approach, combining insights from organizational management and identity (reputation signalling, organizational values), corporate communications (message content and framing), financial markets (stock price performance) issues management and social change movements (legitimacy, stakeholder perceptions of a firm's social activism). The focus lies on building an understanding of how a firm's public stance on a social-political issue can be a salient signal of the firm's values, identity and reputation, as well as exploring the extent to which the way that the firm legitimises its stance can influence investor evaluations of the firm, contributing to its stock market value.

Empirically, we address these questions by employing data on announcements by US firms to side with activists on the boycott campaign in June 2020 targeted at Facebook, Inc. The boycott campaign, called Stop Hate for Profit by the activist groups that started it, claimed that Facebook was profiting from allowing hate speech and misinformation to spread on its platform and therefore urged companies across America to halt all advertisements on Facebook in order to pressure the company to re-evaluate its policies which are alleged to enable the spread of hateful, misinformed and divisive information (Rawlings, 2020; Walker, 2020).

There are several reasons why this campaign offers an appropriate setting in which to explore the relationship between organizations' convictions and values, their decision to engage in CSA (as represented by their boycott of Facebook), and the impact on their financial performance (as measured by short term abnormal returns). First, the issues that the campaign calls attention to-which are the spread of online hate speech, misinformation and discrimination-are viewed as going against the grain of First Amendment protection of free speech, and therefore controversial [1,2]. Also, the justifications provided by firms for their decisions to join the boycott, and how they were framed, can play an important role in influencing not only stakeholders' perceptions of the firms' actions but also how the value of the actions is determined in the stock market (Benford and Snow, 2002; Pollock and Rindova, 2003; Rhee and Fiss, 2014; Zajac and Westphal, 2004).

Accordingly, given the potential for mixed-method research to identify and characterize causal processes and to provide rich understandings of complex and multifaceted phenomenon, such as the role of companies in influencing societal change (Molina-Azorin et al., 2017; Starr, 2014), a mixed-methods design that uses both qualitative techniques (content analysis) and quantitative methods (event study methodology) was employed to address our research questions.

Findings from the qualitative content analysis of company statements show that firms legitimise their stance on, and participation in, the boycott by expressing altruistic values and suggesting to stakeholders that their stance aligns not only with organizational values/ convictions but also with the greater social good. In addition, the event study results indicate that firms who publicly announced their intention to participate in the boycott, on average, earn a statistically significant positive abnormal return of $2.68 \%$ in the four days immediately after the announcements.

Overall, this study makes three contributions to academic research. First, it contributes to the literature on boycotts. Current research on boycotts suggests two main mechanisms 
through which boycotters can hurt the targeted firm. The first is through their ability to divert revenue from the targeted firm (Friedman, 1999), and the second is through their ability to damage the targeted firm's reputation (Whetten and Mackey, 2002; King, 2008). As many studies have shown, both of these forms of threat-declines in revenues or reputation-can destroy the targeted firm's market value (e.g. Afego et al., 2020; Ding et al., 2020; Friedman, 1999; Heilmann, 2016; King, 2008; Pruitt and Friedman, 1986; Tomlin, 2019; Whetten and Mackey, 2002). However, while these studies have offered important insights on the impact on the targeted firms, evidence as to whether a boycott action has any impact on the boycotters is lacking. The present study shows that boycott participation, conceptualized as a cue of a corporation's stand on a social-political issue, can affect the stock price of the boycotter. To the best of our knowledge, this study is among the first to offer empirical evidence that enhances the understanding of the stock price impact of boycott actions from the perspective of boycotters.

Second, it contributes to the emergent literature on the association between CSA and firm financial performance. Previous studies have mainly used consumer purchasing intent and brand loyalty as proxy for financial performance, and employed mostly survey or social media data (e.g. Dodd and Supa, 2014, 2015; Mikeska and Harvey, 2015; Chatterji and Toffel, 2019; Park and Jiang, 2020) [3]. The present study extends the empirical literature by taking a stock market perspective, and using stock returns as a measure of firm financial performance, to better understand values/identity signalling within the context of CSA actions [4]. Furthermore, by taking an interdisciplinary approach and combining quantitative and qualitative techniques, this study facilitates a richer and more comprehensive understanding of the theory and mechanism(s) by which a firms's engagement with CSA, and how it is conveyed, may significantly affect the firm's reputation and, consequently, its stock performance.

Finally, this study contributes to the body of work that examines the role of non-financial information on investor valuation of firms (e.g. Amir and Lev, 1996; Lev, 2004; Laskin, 2016; Ragas and Laskin, 2014). More specifically, this study demonstrates that, regarding nonfinancial information items that can be used by investors in their firm valuation decisions, corporate stances on social-political issues matter.

The remainder of the paper is organized as follows. Section 2 briefly discusses the literature on CSA, stakeholder engagement, issues management, corporate communications social movements and organizational identity theories, and then proceeds to develop the research hypothesis. Section 3 covers the data and methods used in the empirical analyses. We present the results in Section 4 and discuss their implications in Section 5. Section 6 concludes.

\section{Literature review and hypothesis development}

This literature review introduces the theories on which this study is based. In particular, it discusses that ways that notions of CSA intersect with several strands of the literature, including stakeholder theory (Freeman, 1984; Freeman et al., 2000), organizational identity (Albert and Whetten, 1985; Ashforth and Mael, 1996), signaling theory (Spence, 1974), corporate communications theory (Cornelissen, 2004), social issues management (Hallahan, 2001) and boycott behaviours (King, 2008; Manheim, 2001).

\subsection{Corporate social advocacy and stakeholder theory perspective}

The term CSA was coined by Dodd and Supa $(2014,2015)$ to refer to a company's public stance on a contentious social-political issue. Importantly, the issue addressed by the company lies outside the normal sphere of its corporate social responsibility (CSR) activities
Corporate social advocacy signal 
JCMS 5,1

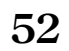

and therefore has the potential to elicit conflicting reactions from different stakeholder groups (Dodd and Supa, 2015).

We identify two major schools of thought which differ in their orientation about why CSA actions may or may not impact financial performance. On the one hand, the traditional view of "shareholder capitalism" suggests that taking stances on social issues or aligning with social causes (e.g. gender diversity and racial equity) reflects the agency problem whereby firm managers demonstrate self-serving behaviour at the expense of shareholders (Barnea and Rubin, 2010; Bénabou and Tirole, 2010; Masulis and Reza, 2015; Ferrell et al., 2016). From this perspective, firm managers who invest in CSA or promote social causes do so to boost their personal image and social reputation among secondary stakeholders such as the media, local politicians and activist groups (Cheng et al., 2014). But such activities are considered "wasteful" and might be interpreted as evidence that management is diverting resources away from "core business" areas at the expense of maximizing shareholder value (Cook and Glass, 2014; Shleifer and Vishny, 1989; La Porta et al., 2000; King 2008). Moreover, engaging in CSA may polarize stakeholders (Coombs and Holladay, 2018; Weinzimmer and Esken, 2016). As a result, market actors may not interpret news about a firm's involvement in CSA as beneficial to the firm's future financial prospects and means that engaging in CSA might not improve or would even hurt the firm's financial performance.

Empirically, however, the findings have been mixed. For example, while Kiliç and Kuzey (2016) show that gender leadership diversity initiatives (i.e. the inclusion of female members on company boards) in Turkey enhances the financial performance of firms, Ahern and Dittmar (2012) find significant declines in stock value of Norwegian companies after the mandate requiring $40 \%$ of directors to be female took effect. Similarly, Cook and Glass (2011) examined stock price response to being named one of the "Best Companies for Minorities" and found significant decline in stock price of companies that were named for the award.

On the other hand, studies at the intersection of ethical consumerism and stakeholder theory (Freeman et al., 2000; Hörisch et al., 2014) point to the business case for CSA. That is, a commitment to actively engage and align with social causes that affect a broader group of stakeholders can improve financial performance. For example, CSA efforts can positively impact financial performance through consumers' purchasing intent, altruistic values and positive brand perception, all of which may increase the likelihood of consumers choosing the products of businesses that share their values (Dodd and Supa, 2014; Mikeska and Harvey, 2015; Chatterji and Toffel, 2019; Park and Jiang, 2020) [5]. Promoting values that they care about may also help firms to attract employees who are more motivated to perform, in part because of the opportunity to contribute to substantial social change. Next, we discuss the role of organizational identity in influencing CSA behaviours, including how company values, as revealed by a corporation's public stand on a social issue, may be utilized as an uncomplicated decision tool by investors looking to form impressions about the corporation.

\subsection{Organizational identity, social issues management and corporate communication}

The literature on organizational identity suggests that information highlighting an organization's distinctive culture (e.g. its policies or practices around gender/racial equality and diversity, parental leave, etc.) is an important means of conveying the organization's identity (Albert and Whetten, 1985; Ashforth and Mael, 1996; Jones and Murrell, 2001). In this context, CSA provides a potentially veritable medium for a firm to convey its distinctiveness in terms of how it views specific social issues, relative to other firms. From this perspective, the firm's public stance on an issue can be a salient signal of what the firm values and believes to benefit the greater good. This signal could then be used by individuals who are seeking to form impressions about the firm's values, identity and character (Jones and Murrell, 2001), which in turn can facilitate their decisions about whether they want to invest in the firm. 
As mentioned earlier, activist-stakeholders are mounting increasing pressure on companies to take a stand on potentially contentious social issues with the goal of contributing to progressive social change (Chatterji and Toffel, 2019). In addition, publics increasingly expect companies to engage with issues of social and political significance (Wettstein and Baur, 2016), such as reforming systems that sustain different forms of inequalities or inequities in the context of society. As a result, many firms are expending significant resources in an attempt to positively affect social change, in part because it allows them to gain legitimacy from diverse stakeholder groups (Coombs and Holladay, 2018; Rim et al., 2020) and, at the same time, enhances their overall reputation within the market.

Central to the role that corporations can play in influencing social change is the concept of issues management (Sommerfeldt and Yang, 2017). Broadly defined, issues management encapsulates an organization's efforts to monitor its environment and communicate with publics about matters of public contention in ways that generate an advantageous outcome for the organization (Bowen, 2004; Hallahan, 2001; Sommerfeldt and Yang, 2017). As a strategy, issues management is predicated on the notion that corporations can and should actively contribute to shaping public policy and that doing so could benefit the organization and its stakeholders (Crable and Vibbert, 1985; Sommerfeldt and Yang, 2017; Heath and Palenchar, 2009). Critical to the success of issues management strategy, however, is the role of framing (Hallahan, 2001). The role of (message) framing in collective action efforts, such as boycotts, is to define the issue in need of change, point out who is to blame, create an alternative course of action, and to encourage others to act together (Benford and Snow, 2000; Sommerfeldt and Yang, 2017). Indeed, previous research has suggested that corporations can use communication in specific ways to change attitudes towards controversial social issues and, in doing so, influence many aspects of society (Parcha and Kingsley Westerman, 2020).

Next, we explain our own connections of boycott behaviours with CSA, arguing that boycott participation can be an important cue of a corporation's stand on a contentious social issue which in turn can contribute to the corporation's stock market value.

\subsection{Social change movements, boycott behaviours and stock market performance}

Social change movements are groups of individuals banded together, either formally or informally, to pursue or resist social change (Edwards and McCarthy, 2004; Sommerfeldt and Yang, 2017). As Gopaldas (2014) argued, social change actors, such as activists, generate sentiments about the values that they stand for or that they believe can benefit society (e.g. gender diversity, animal rights, environmental protection, transgender rights etc.) Corporations and their brands may then use such sentiments to engage consumers, and ultimately, increase their sales (Gopaldas, 2014).

Boycotts are a classic tactic for social change movements (Manheim, 2001) and are widely used by activists trying to persuade corporate targets to adopt some change in practice or policy (King, 2008; Manheim, 2001). Targeting corporations through this means give activists a medium to directly address their grievances as well as influence a company to amend an undesirable policy or practice (King and Soule, 2007; Lenox and Eesley, 2009; King and McDonnell, 2012). By making negative claims about the corporation, activists' attack not only tarnishes the image and reputation but also threatens the corporation's legitimacy (Whetten and Mackey, 2002; King, 2008; McDonnell and King, 2013; Ding et al., 2020). As a result, firms are increasingly recognizing the importance of communicating positive information about their social change advocacy efforts as a way of gaining legitimacy from diverse stakeholder groups, including activist organizations (Coombs and Holladay, 2018; Rim et al., 2020).

Thus far, the literature that examines the stock price effects of boycotts focuses mostly on the ability of boycotters to impose sufficient financial and reputational harm on the targeted firm and ultimately depress its share price (e.g. Pruitt and Friedman, 1986; Tomlin et al., 2019). 
JCMS 5,1

\section{4}

In contrast, as a point of departure, we argue that boycott participation can be a cue of a corporation's public stance on a socially-charged issue that can affect stakeholder perceptions of the corporation's stance which in turn can affect the corporation's financial outcomes. We suggest that the actions of corporations, as represented by their boycott of Facebook, are not meant merely to pressure the firm into amending its policies but are also intended to be seen as a form of CSA, i.e. to publicly communicate their stance and support for positive action against hate speech, misinformation and discrimination in society. Therefore, when perceived as a form of CSA, boycott participation announcements by firms can generate positive stakeholder perceptions which are associated positively with the firm's short-term stock performance.

In light of all of the above, and building on the importance of organizational identity in motivating social advocacy behaviours of companies (Eilert and Nappier Cherup, 2020), as well as the role of reputation signalling and corporate communication, we argue that social advocacy-based signals (i.e. a firm's publicly announced commitment to side with activists in the fight against hateful, misinformed and divisive information in society), and how they are conveyed, will be interpreted by signal receivers (i.e. investors), thereby impacting share price. More specifically, from press releases regarding a corporation's commitment to contributing to positive social change (through a boycott action), investors and traders can learn that a firm is taking the lead to push on societal issues (e.g. on racial inequality, gender inequality, sexual orientation discrimination and other forms of inequalities or inequities in the context of society). Such information highlighting an organization's stand on these issues can be used to signal to market actors the organization's ideologies and virtues related to enhancing or restoring fairness for disadvantaged groups, allowing the organization to build, enhance or defend its reputation based on its projected corporate identity (Ashforth and Mael, 1996; Cartabuke et al., 2019; Jones and Murrell, 2001).

Thus, to understand how a firm communicates its stand on contentious social issues, as well as to understand the motives, values and beliefs underlying the decision to get involved, including how the firm legitimises its involvement, we employ a qualitative content analysis of company statements that directly reference the issues around the Facebook boycott. In addition, in regard to a public announcement of an event revealing new information about a firm's CSA efforts, we offer the hypothesis that: announcement of a firm's engagement with CSA, as represented by their boycott of Facebook over its alleged promotion of hate speech and discrimination, will positively impact the firm's reputation, as well as its short term stock market performance. This is tested using the event study methodology which is described in the next section alongside the methodology of content analysis.

\section{Sample and methods}

\subsection{Sample and firm characteristics}

Our sample period starts on June 17, 2020, when the coalition of civil rights and activist groups in America launched the Stop Hate for Profit advertiser boycott campaign targeted at Facebook and extends to July 2, 2020, when the actual boycott action began. Although a large number of small, privately-owned businesses joined the campaign, we focus mainly on publicly traded companies, given that our objective is to understand whether the stock market reacts to a firm's decision to join the boycott. Consequently, our universe is limited to companies listed on the NASDAQ and NYSE.

Manual web searches were conducted for announcements by companies to join the boycott [6]. We retrieved a modest sample of 27 announcement events that occurred during this period. Table 1 provides a snapshot of the sample companies. As can be deduced, majority of the companies belong to the consumer goods sector, as defined by the Bloomberg Industry Classification Standard (BICS). Media reports suggest that the advertising budget 


\begin{tabular}{|c|c|c|c|}
\hline Company & Industry sector & Announcement date & Corporat \\
\hline Adidas & Consumer discretionary & $6 / 29 / 2020$ & advocacy \\
\hline Bausch Health Companies & Healthcare & $6 / 30 / 2020$ & \\
\hline Best Buy & Consumer discretionary & $6 / 28 / 2020$ & \\
\hline Broadmark Realty Capital & Financials & $6 / 30 / 2020$ & \\
\hline Clorox & Consumer staples & $6 / 29 / 2020$ & \\
\hline Coca-Cola & Consumer staples & $6 / 26 / 2020$ & 5 \\
\hline Colgate-Palmolive & Consumer staples & $6 / 29 / 2020$ & \\
\hline CVS Health Corp & Healthcare & $6 / 29 / 2020$ & \\
\hline Denny's Corp & Consumer discretionary & $6 / 29 / 2020$ & \\
\hline Diageo & Consumer staples & $6 / 30 / 2020$ & \\
\hline Dunkin Brands Corp & Consumer discretionary & $7 / 1 / 2020$ & \\
\hline Ford Motor Company & Consumer discretionary & $6 / 29 / 2020$ & \\
\hline Honda Motor Company & Consumer discretionary & $6 / 26 / 2020$ & \\
\hline $\mathrm{HP}$ & Technology & $6 / 29 / 2020$ & \\
\hline JM Smucker Company & Consumer staples & $6 / 30 / 2020$ & \\
\hline Levi Strauss & Consumer discretionary & $6 / 26 / 2020$ & \\
\hline Microsoft & Technology & $6 / 30 / 2020$ & \\
\hline Pfizer & Healthcare & $6 / 29 / 2020$ & \\
\hline Sony Corp. of America & Technology & $7 / 2 / 2020$ & Table 1. \\
\hline Starbucks & Consumer discretionary & $6 / 29 / 2020$ & S? \\
\hline Suntory Beverage \&Food & Consumer staples & $6 / 28 / 2020$ & $2 x^{2}$ \\
\hline Target Corp & Consumer staples & $7 / 1 / 2020$ & $\begin{array}{l}\text { announced their } \\
\text { decision to ioin the }\end{array}$ \\
\hline The Hershey Company & Consumer staples & $6 / 26 / 2020$ & $\begin{array}{l}\text { decision to join the } \\
\text { boycott campaign }\end{array}$ \\
\hline Unilever & Consumer staples & $6 / 26 / 2020$ & $\begin{array}{l}\text { Doycott campaign } \\
\text { targeted at Facebook in }\end{array}$ \\
\hline Upwork & Communications & $6 / 19 / 2020$ & June 2020 over issues \\
\hline Verizon & Communications & $6 / 25 / 2020$ & of hate speech and \\
\hline Vertex Pharmaceuticals & Healthcare & $6 / 29 / 2020$ & misinformation on it \\
\hline Walgreens Boots Alliance & Consumer staples & $7 / 1 / 2020$ & platform \\
\hline
\end{tabular}

on Facebook varies substantially among companies that supported the boycott. However, among the sample companies examined in this study, Unilever and Verizon-with an estimated spend of $\$ 42 \mathrm{~m}$ and $\$ 23 \mathrm{~m}$ respectively-were ranked among the top 100 advertisers on Facebook in 2019 [7].

A variety of media channels was used to announce, for the first time, company decisions to join the boycott. These include press releases on company websites, official Twitter accounts, LinkedIn pages and blogs. For announcement days that fall on a weekend, we take the following (trading day) Monday to be the announcement day.

\subsection{Qualitative content analysis}

Content analysis is a methodology used to make valid or replicable inferences from text (Krippendorf, 2004). The methodology is used in a variety of fields to identify and analyse themes present in organizational statements (Creamer and Ghoston, 2013). In the context of this study, the methodology allows us to identify the motives, values and beliefs endorsed by corporations as it pertains to their involvement in the issues that the boycott sought to call attention to.

As noted, previous research suggests that activists generate sentiments about the values they stand for or the type of society they want (Gopaldas, 2014). Corporations then integrate such values into their brand identity propositions or existing policies and, with that, engage investors, consumers, employees and other stakeholders, ultimately enhancing their legitimacy (Coombs and Holladay, 2018; Gobe, 2001; Gopaldas, 2014; Rim et al., 2020). 
JCMS 5,1
Studies also suggest that the role of framing in collective action efforts, such as boycotts, is to first define the issue in need of change, point out who is to blame, create an alternative course of action, and finally encourage others to act together (Benford and Snow, 2000; Sommerfeldt and Yang, 2017). Thus for each firm in our sample, we identified company statements adjoined to the boycott participation announcements and considered what the key motives or messages (values and beliefs) were and how they were framed. We then perform a content analysis of company statements to understand how firms communicated their decisions to participate in the boycott, the motives underlying their decisions to get involved, as well as how they legitimised their involvement.

\subsection{Event study methodology}

In the context of CSA actions, boycott participation decisions can be a relevant source of new information for a firm's stakeholders which can alter the level of resource support and legitimacy the firm enjoys (Conaway and Wardrope, 2010; Patelli and Pedrini, 2014)-and in turn influence how the value of the firm is determined in the stock market. Importantly, to the extent that a firm's decision to participate in the boycott constitutes an unexpected news about the firm, an event study can provide reasonable clues of a causal relation between the firm's decision and its share price performance (Atanasov and Black, 2016; Sorescu et al., 2017). Thus, we conduct an event study around the boycott participation announcement dates to assess the potential impact on stock prices of announcing firms. The event study methodology has been used to analyse the impact of boycotts on targeted firms' stock prices (Heilmann, 2016; Tomlin, 2019), and is the ideal means, we believe, for testing whether CSA can serve a signalling function for individuals evaluating a firm for an investment decision because it is the typical method used to assess the impact of various firm actions on firms' financial performance. In addition, the methodology is ideally suited for this research because it is robust to limited sample sizes (Ait-Sahalia et al., 2012).

In this study's context, events are announcements made by firms about their intention to side with activists on the boycott campaign. To assess the event's impact, one needs a measure of the normal return, abnormal return and cumulative abnormal return. Normal return is defined as the expected return if the event did not take place. The abnormal return is the actual ex-post return of the stock over the event window minus the normal return of the stock over the event window. Cumulative abnormal return is the sum of abnormal returns, which allows us to draw inferences about the price effects of boycott participation announcements over several intervals.

Two models, the constant mean return model and the market model, are often used for calculating the normal return. However, when daily data are used, the variance of the abnormal return is not reduced by much by choosing one or the other model (Campbell et al., 1997). Therefore, following Ju et al. (2014), we use the constant mean return model, which assumes that the mean return of a given security is constant over time. The normal return for each firm $i$ was calculated using the constant mean return model as Eq. (1):

$$
\widehat{R}_{i \tau}=\mu_{i}+\zeta_{i \tau}
$$

where $\widehat{R}_{i \tau}$ is the normal return for firm $i$ at period $\tau, \mu_{i}$ is the mean return for security $i$ calculated as the average return during the 200 -day estimation window $(-210,-11)$ and $\zeta_{i \tau}$ is the disturbance term. To determine the market reaction for each firm that announced a decision to join the boycott, the abnormal returns (AR) were calculated as the difference between the observed returns and the normal returns as Eq. (2):

$$
\mathrm{AR}_{i \tau}=R_{i \tau}-\widehat{R}_{i \tau}
$$


where $\mathrm{AR}_{i \tau}$ is the abnormal return for firm $i$ at period $\tau, R_{i \tau}$ is the observed return for firm $i$ at period $\tau$ and $\widehat{R}_{i \tau}$ is the normal return for firm $i$ at period $\tau$. To control for confounding events, we follow Otchere and Ross (2002) and assess only the short-term effects, i.e. the abnormal returns of each firm for each of the ten days around the event $(-5,+5)$. The daily abnormal returns were then aggregated over various event windows to obtain the cumulative abnormal return (CAR) as in Eq. (3):

$$
\mathrm{CAR}_{i \tau}=\sum_{\tau=T_{1}+1}^{T_{2}} \mathrm{AR}_{i \tau}
$$

Corporate social advocacy signal

where $\mathrm{CAR}_{i \tau}$ is the cumulative abnormal return for firm $i$ over a specified event window, $T_{1}$ is the beginning of that event window and $T_{2}$ is the end of that event window. Next, the ARs and CARs were averaged across firms in order to draw inferences about the (short term) impact of the boycott participation announcements. To ensure robustness, we use three measures to test the statistical significance of the AR and CAR. The first is the standard parametric $t$-statistic which assumes, among other things, that the abnormal returns of sample firms are cross-sectionally independent. Given that some announcing firms have a common event date, we also use the Boehmer et al. (1991) parametric $t$-statistic to minimize the potential bias caused by cross-sectional dependence in the abnormal return data. Finally, we use the nonparametric generalized sign test (Cowan, 1992) which holds well for small samples as well as for data that are non-normally distributed.

\section{Results}

In this section, a summary of the results of the analyses is organized by method of analysis and research question.

\subsection{Qualitative content analysis}

A qualitative content analysis is used to answer on the question: how did firms justify their stand on the issues that the boycott sought to address and what motives, values and beliefs are identified in the company statements that conveyed their stand?

As noted in the preceding section, we identified company statements adjoined to the boycott participation announcements and considered what the key motives or messages (values and beliefs) were and how they were framed. The key motives, values and beliefs that emerged from our content analysis can be divided into six categories. These, together with illustrated examples of how the messages were framed, are presented in Table 2.

Across company statements, hate and discrimination were explicitly characterized as undesirable in society, thus creating a context for justifying participation in the boycott. For example Adidas' statement said: “. . . discriminatory and hateful online content has no place in our brand or in society." By framing its message in this way, the company is, in effect, calling attention to its values as a brand and, in doing so, enhancing its corporate reputation and legitimacy among diverse stakeholders.

Firms also appeared to justify their actions by framing it as an effort to contribute to strengthening social cohesion in society and to help influence positive social change. For instance, in its statement, Suntory said: "We stand up for what's right and we stand with all who are committed to the fight against hate speech, racism and prejudice. We hope this collective action helps catalyze positive change and accountability...”.

In other examples, firms contextualized their decision as an effort aimed at promoting safe spaces and communities. For instance the statement from Pfizer said: "... we are asking Facebook to take proactive steps to ensure their platforms are safe and trusted spaces for all.” 


\section{JCMS} 5,1

\section{8}

Standing together and contributing to positive social change

Helping to promote safe spaces and communities

Championing the values of human respect and dignity

Embracing efforts to strengthen accountability and transparency within Internet organizations

Championing the values of inclusion, inclusivity and diversity
Illustrative examples of message framing

"Racist, discriminatory, and hateful online content have no place in our brand or in society. As we focus on better practices within our company and communities to ensure lasting change in the fight against racism, Adidas and Reebok will also pause advertising on Facebook..." (Adidas)

"At Bausch Health, we're pausing all paid advertising on Facebook in alignment with the \#StopHateForProfit Boycott. . . We feel this is a natural step forward ... and are proud to align ourselves with likeminded companies who refuse to stand for hate and disinformation being spread on our advertising platforms" (Bausch Health Companies)

"We stand up for what's right, and we stand with all who are committed to the fight against hate speech, racism and prejudice. We hope this collective action helps catalyse positive change and accountability" (Suntory)

"As a company, we stand for the values of togetherness and inclusion and we are resolute in our commitment to make a difference and be part of positive change" (The Hershey Company)

"In support of the \#StopHateForProfit campaign, we have globally suspended our Facebook and Instagram activity... We stand for working (and playing) together for good" (Sony Corp)

“... we are asking Facebook to take proactive steps to ensure their platforms are safe and trusted spaces for all. We are calling on Facebook to continue listening to the concerns of the

\#StopHateForProfit movement and take action on their product recommendations" (Pfizer)

"We are hopeful that Facebook will take action and make it a safe space for our consumers to communicate and gather" (The Hershey Company)

“.... [we] will withhold [our] advertising on Facebook and Instagram, choosing to stand with people united against hate and racism. This is in alignment with our company's values, which are grounded in human respect" (Honda)

“... we should expect of our social media partners to rid the platforms of hate, violence and inappropriate content. We will let them know we expect greater accountability, action and transparency from them" (Coca-Cola)

We are actively engaged... to drive more accountability, transparency and trusted measurement to clean up the digital and social media ecosystem" (Ford)

"As America's Diner, we offer an inclusive and welcoming environment where all people can enjoy a nice meal and we strongly oppose hate speech of any kind. It is our belief that Facebook has not done enough to address this important issue on its platform and we are calling on Facebook to make positive changes to its process for combatting hate speech and disinformation" (Denny's Corporation) "Using our Basic Beliefs as guideposts, we are in the early stages of efforts to enhance the inclusivity of our workplace and to become a more diverse company. Despite being at this stage of our journey, we understand [that] one immediate opportunity is to ensure the money we are spending to market our brands and products is going to companies that understand the importance of eliminating hate speech and discriminatory content from society" (J.M Smucker)

"We believe in bringing communities together, both in person and online, and we stand against hate speech. We believe more must be done to create welcoming and inclusive online communities, and we believe both business leaders and policy makers need to come together to affect real change." (Starbucks)
Table 2.

Firms' strategic actions and framing of their position on the issues that the campaign calls attention to 
Similarly, The Hershey Company stated: "We are hopeful that Facebook will take action and make it a safe space for our consumers to communicate and gather."

A number of firms also conveyed the legitimacy of their actions through a diversity/ inclusion lens. Take as an example the statement by Denny's Corporation: "As America's Diner, we offer an inclusive and welcoming environment where all people can enjoy a nice meal and we strongly oppose hate speech of any kind. .." Similar views were expressed by J.M Smucker: "Using our Basic Beliefs as guideposts, we are in the early stages of efforts to enhance the inclusivity of our workplace and to become a more diverse company... we understand [that] one immediate opportunity is to ensure the money we are spending to market our brands and products is going to companies that understand the importance of eliminating hate speech and discriminatory content from society." This is consistent with arguments in the corporate communications literature asserting that firms that advocate for a social issue tend to connect the issue to existing policies concerning their employees, customers and other stakeholders (Coombs and Holladay, 2018).

Taken together, statements such as these demonstrate the various ways through which firms sought to build and strategically communicate legitimacy for their involvement in the issues that the boycott raise. This is consistent with the notion that in matters of CSA, the company's message should be compelling and authentic to legitimise the company's engagement (e.g. Chatterji and Toffel, 2018; Coombs and Holladay, 2018). It also shows how firms focused on expressing altruistic and prosocial value propositions to enhance their organizational moral identity, which can also cultivate strong stakeholder-brand bonds, ultimately improving the organization's financial bottom line (Gobe, 2001; Gopaldas, 2014). Furthermore, the results echo recent arguments on the need for corporations to convey a positive, strategic tone and to be mindful of how their engagement is being perceived by publics (Rim et al., 2020).

Overall, evidence from the content analysis supports the argument that when a firm adopts a distinct position on a contentious social-political issue, and conveys its position in a positive tone, it can positively influence stakeholder and the public perception of the firm. In particular, it provides insight into how firms legitimise their stance on, and participation in, the boycott by expressing altruistic values and suggesting to stakeholders and the public that their stance aligns not only with organizational values but also with the common social good. That being said, it is possible that for some firms, the real reason for getting involved in the boycott campaign might have been to avoid becoming targets of future activist attacks themselves, as King and McDonnell (2012) suggested. However, managers are not likely to state these reasons because it could negatively affect stakeholder attitudes towards the organization's actions. As it is not possible to ascertain the credibility of the stated reasons for getting involved, we assume that the reasons provided are honest and credible.

\subsection{Event study analysis}

The event study methodology is employed to answer on the question: do announcements of firms' engagement with CSA, as represented by their boycott of Facebook over its alleged promotion of hate speech and discrimination, convey market signals that impact firms' short term stock performance?

Table 3 shows daily mean abnormal returns and $t$-statistics for the five days before and after the announcement day (day 0) regarding a corporation's commitment to participate in the boycott campaign.

The results indicate that firms' abnormal returns are negative and mostly insignificant in the days before the announcement. However, we observe significantly positive abnormal returns of $1.28 \%$ on the day after the announcement day (day +1$)$. Significant positive abnormal returns of $0.59 \%$ are also observed on day +3 . The existence of insignificant abnormal return on day 0 suggests that price reactions occur with a lag, which may be the result of announcements made at or near the close of trade. Importantly, the abnormal returns
Corporate social advocacy signal 


\section{JCMS 5,1}

60

1

2

3

4

5

Table 3.

Daily abnormal returns (ARs) for boycott supporting firms

\begin{tabular}{lllcr}
\hline Day & AR & t-test & Boehmer et al. test & Sign test \\
\hline-5 & $-0.39 \%$ & -1.05 & -1.61 & -1.64 \\
-4 & $-0.09 \%$ & -0.23 & -0.72 & -0.87 \\
-3 & $-1.12 \%$ & $-3.24^{* * * *}$ & $-4.11^{* * *}$ & $-3.18^{* * *}$ \\
-2 & $-0.43 \%$ & -0.68 & -1.03 & -0.10 \\
-1 & $-0.10 \%$ & -0.22 & -0.31 & -0.10 \\
0 & $-0.21 \%$ & -0.50 & -0.38 & -0.10 \\
1 & $1.28 \%$ & $2.59^{* * *}$ & $2.55^{* *}$ & $2.99^{* * *}$ \\
2 & $0.29 \%$ & 0.98 & 1.16 & -0.48 \\
3 & $0.59 \%$ & $1.65^{*}$ & $2.16^{* *}$ & $2.60^{* * *}$ \\
4 & $0.52 \%$ & 1.14 & 1.59 & 1.45 \\
5 & $-0.39 \%$ & -0.68 & -0.66 & -1.25
\end{tabular}

Note(s): This table shows the daily abnormal returns (ARs) for boycott supporting firms for each day of the event window. Day 0 is the announcement day (the day firms publicly announced their intention to support the campaign). The $t$ statistic reflects a two-tailed test that the average abnormal returns are different from zero. $* * *, * *$, and $*$ indicate statistical significance at the $1 \%, 5 \%$ and $10 \%$ level, respectively

on day +1 and day +3 suggest that investors can earn a statistically significant abnormal return after the announcement is made. On the whole, the announcements appear to signal positive information about the values and organizational identity of the firms that announced their decision to participate in the boycott.

We also calculate cumulative abnormal returns for different event windows. As with daily abnormal return, the null hypothesis here is that the cumulative abnormal return is zero. Table 4 shows cumulative abnormal returns (CARs) and $t$-statistics over several windows. The CARs over the five-day and three-day pre-announcement windows $(-5,-1)$ and $(-3,-1)$ are negative.

In contrast, CARs for the two-day post-announcement window $(+1,+2)$ show significant positive share price effects of $1.57 \%$. When the post-event window is expanded to include additional days $(+1,+3),(+1,+4)$ and $(+1,5)$, the CARs increase to $2.16 \%, 2.68$ and $2.30 \%$, respectively. In sum, the largest significant positive price reaction of $2.68 \%$ occurs in the fourday post-announcement window $(+1,+4)$. When considered over the full 11-day window $(-5,+5)$, the results suggest that the price effects are temporary as prices appear to revert to their pre-announcement levels. This finding is consistent with price pressure effects and suggests that the abnormal returns are likely to be driven by trading pressure.

Table 4.

Cumulative abnormal returns (CARs) for boycott supporting firms

\begin{tabular}{lcccc}
\hline Event window & CAR & $t$-test & Boehmer et al. test & Sign test \\
\hline$(-5,-1)$ & $-2.13 \%$ & $-3.12^{* * *}$ & $-4.11^{* * * *}$ & $-3.95^{* * * *}$ \\
$(-3,-1)$ & $-1.65 \%$ & $-4.51^{* * *}$ & $-4.34^{* * *}$ & $-3.57^{* * *}$ \\
$(-5,+5)$ & $-0.04 \%$ & -0.03 & -0.48 & -1.25 \\
$(-4,+4)$ & $0.73 \%$ & 0.72 & 0.49 & 1.06 \\
$(-3,+3)$ & $0.30 \%$ & 0.51 & 0.09 & 0.29 \\
$(-2,+2)$ & $0.83 \%$ & 1.05 & 0.90 & 0.68 \\
$(-1,+1)$ & $0.97 \%$ & 1.47 & 1.3 & 1.06 \\
$(+1,+2)$ & $1.57 \%$ & $2.85^{* * *}$ & $3.02^{* * *}$ & $1.83^{*}$ \\
$(+1,+3)$ & $2.16 \%$ & $3.68^{* * *}$ & $4.12^{* * *}$ & $2.22^{* * *}$ \\
$(+1,+4)$ & $2.68 \%$ & $3.72^{* * *}$ & $4.76^{* * *}$ & $4.14^{* * *}$ \\
$(+1,+5)$ & $2.30 \%$ & $2.42^{* * *}$ & $3.03^{* * *}$ & 1.45
\end{tabular}

Note(s): This table shows the cumulative abnormal returns (CARs) for boycott supporting firms over several intervals within the event window. The $t$ statistic reflects a two-tailed test that the cumulative abnormal returns are different from zero. $* * * * *$, and * indicate statistical significance at the $1 \%, 5 \%$ and $10 \%$ level, respectively 
Taken together, the event study result - which shows that firms who publicly announced their commitment to boycott Facebook experienced significant positive abnormal returns of $2.68 \%$ in the four days immediately after the announcement - supports our conjecture that public announcement of a firm's engagement with CSA, as represented by their boycott of Facebook over its alleged promotion of hate speech and misinformation, provides positive market signals of organizational identity and overall reputation of the firms, which is priced [8].

\section{Discussion and implications}

The content analysis provides interesting insights into how firms strategically communicate legitimacy for their involvement in, and their stand on, the issues that the boycott campaign addresses. Specifically, it shows evidence consistent with the notion that in matters of social advocacy, firms' actions gear towards framing the issue in a positive manner and advancing their legitimacy, reputation, moral identity and brand value propositions in ways that align with their stance on the issue (e.g. Coombs and Holladay, 2018; Gopaldas, 2014). It also shows how firms legitimise their involvement by suggesting that their stance on the issue aligns with the greater social good. This is consistent with the idea that firms need to establish to stakeholders that their actions are useful to the broader society (Coombs and Holladay, 2018). It also shows parallels with the view that paying attention to multiple stakeholders, including society, "secures tangible and intangible resources (including knowledge and reputation) that may ultimately create organizational wealth or value for shareholders" (Hillebrand et al., 2015, p. 413), which is also in line with arguments in the issues management literature that asserts that firms can create value by getting involved in issues that are of interest to the broader society (Dodd and Supa, 2014).

With respect to the event study analysis, we observe that a company's stock price gains a statistically significant abnormal return of $2.68 \%$ in the four days immediately following news of its support for the campaign, which suggests that market participants positively viewed the decision to join the campaign. This finding corroborates those of Dodd and Supa (2014, 2015), Mikeska and Harvey (2015) and Chatterji and Toffel (2019), who found that corporate stances on social issues significantly impact financial performance, as measured by consumer purchase intention.

Taken together, the boycott participation announcements are informationally strategic, as the content analysis has shown, and that market reacts positively over the short-term, as indicated by a significant but temporary increase in abnormal returns following the announcements. In all, boycott participation as a form of CSA can generate positive signals about organizational values and in turn positively influence stock market reaction. The logic supporting this finding is as follows: Stakeholders and investors are more likely to accept a firm's CSA reputation as legitimate when that firm is seen to be "walking the talk" on issues they are advocating for. In this study's context, corporations took the decision to join a boycott, not only to pressure the targeted firm (Facebook) to change its policies, but also as a means of communicating their values with regard to the issues that the campaign calls attention to, i.e. hate speech, misinformation and discrimination in society. When considered in combination with organizational identity, one can have a better appreciation of how communicating company position on such issues can generate positive perception and goodwill for the corporation, especially among stakeholders and members of the public who already support the corporation's position (Chatterji and Toffel, 2019). The findings also lend credence to the notion that adopting issues management as a strategic communication approach can benefit firms, as it can help drive their advocacy efforts in ways that generate positive stakeholder attitudes towards the corporation's stance on the issue.
Corporate social advocacy signal 
JCMS 5,1

62

Although one should be careful about generalizing conclusions from a small sample, the 27 boycott participation events tell an interesting story. Subject to this caveat, several implications can be drawn. First, from a theoretical perspective, the findings suggest that it would serve researchers well to recognize the interconnections among stakeholder, organizational identity and corporate communication theories when considering how a firm's social advocacy actions may lead to a positive (or negative) assessment from stakeholders which can reflect, also, in financial performance. In addition, findings from the qualitative content analysis underscore the relevance of corporate stances on social issues as important nonfinancial information items that can be used by investors in their firm valuation decisions.

Insights from the study also provide a practical resource that can be used to inform investor and managerial decision making about such issues. As the study by Coombs and Holladay (2018) demonstrates, the framing of such stances has a significant impact on how the firm's CSA efforts may be received by stakeholders. Our findings, therefore, can help corporate managers develop a systematic approach to CSA by understanding how the company can best communicate its views on important societal issues. Also, by presenting abnormal stock return behaviour around the announcements, the findings offer practical insights for investors and arbitrageurs on the timing of trades around CSA actions. Furthermore, for firm managers, it suggests that taking the lead to push on social issues, such as hate speech, misinformation, among others, and communicating their position in a way that speaks to their values and to the common good, could be rewarding. The benefits to these firms in terms of the positive impact on share prices, as confirmed by this study, may thus encourage firm managers and corporate executives to take active stances on socially-charged matters and by doing so contribute to creating an inclusive society.

On this evidence, and given the tumultuous nature of today's society, one can therefore surmise that, increasingly, companies may become more interested in the more nuanced aspects of social-political and moral life that is often ignored in discussions of CSR (Afego and Alagidede, 2021). As such, there may be both moral and strategic imperatives for corporations to engage with important societal issues and to assume the same duties and obligations as other members of civic society (Park and Jiang, 2020).

\section{Limitations and future work}

This study is of an initial nature and the findings relate to a specific case of a boycott campaign in America that sought to call attention to the social-political issues of hate propaganda and misinformation on social media. Consequently, the analysis is limited to US firms. Although we believe that our findings have wider relevance, future work that considers a broader range of contexts might be required to learn more about the market impacts of CSA actions in other contexts and instances, particularly because the signalling value of CSA actions (in the form of boycott participation as well as in other contexts) may vary across countries due to institutional and cultural differences.

Furthermore, this study used stock market return as the variable of interest in order to demonstrate how CSA actions (in the form of boycott participation) impact financial performance in the short term. However, as Dodd and Supa (2014) explained, involvement in controversial social-political issues could have long-lasting impacts on a firm's reputation. Therefore, future research may consider using other measures of financial performance, such as total assets, sales growth, operating income growth or return on assets, in order to understand the longer-term financial impacts on firms.

In addition, we acknowledge that the sample size of firms is limited. Exploring market reactions using larger sample sizes would be necessary to obtain a more robust understanding of stock market response to CSA actions. Also, because the dynamics of 
market reactions might be different for issues that are more socially charged than the ones examined in this study, future research might do well to consider how market expectations are affected by corporate stances on more contentious social-political issues.

Finally, another limitation to the study, which we hope will be addressed in future work, is with regard to the question of whether stock price reaction occurred only for firms that publicly expressed their commitment to the boycott against Facebook. We acknowledge that focussing only on firms that take the same stance on issues of hate speech, misinformation and discrimination, our sample of event firms does not capture the full corpus of market reaction for this boycott campaign and ideally one would like to compare the stock price behaviour of companies that participated in the boycott with that of companies that did not participate in the boycott. Methodologically, this would be analogous to expanding the asset pricing model to allow for the use of matched controls from non-event firms to determine whether discernible differences in market reactions exist between firms that joined the boycott and those that did not. Thus, we expect future work will tap into methodologies that involve treatment and control samples, in order to deepen the scope of our understanding of stock market response to CSA actions.

\section{Notes}

1. See The Verge, "Facebook's CEO rallies people around the First Amendment", 17 October, 2019, available at https:/www.theverge.com/2019/10/17/20919223/mark-zuckerberg-facebook-speechlive-politics-threats-free-expression (accessed on 17 September 2020)

2. See The Guardian, "Facebook's commitment to free speech will "piss people off", Zuckerberg says'1 February, 2020, available at https://www.theguardian.com/technology/2020/feb/01/facebookpolitical-ads-zuckerberg (accessed on 16 September 2020).

3. Dodd and Supa (2014) examine how CSA impacts organizational financial goals via consumer purchase intentions. Their study, which focused on corporations that had taken public stances on issues such as health care reform, emergency contraception and same-sex marriage, concludes that CSA for these issues significantly impacts consumer purchasing intention and brand perception and, therefore, affects the likelihood of consumers choosing the products of businesses that share their views. Similarly, Mikeska and Harvey (2015) and Chatterji and Toffel (2019) document evidence of changes in consumer purchasing intention towards the product a CEO represents after that CEO makes public their social and political beliefs on climate change, human rights and same-sex marriage. Park and Jiang (2020), using online surveys, find that CSA engagement affects the way individuals in the social media environment view a corporation as well as their loyalty to the brand the corporation represents.

4. The event study methodology is the typical method used to identify the change in share price that is directly attributable to a signal generated by various firm actions over the short term (Bash and Alsaifi, 2019; Cook and Glass, 2014). The methodology therefore is well-suited for testing whether CSA can serve a signaling function for investment decision-making.

5. Consistent with this view, a recent survey found that $87 \%$ of American consumers will purchase a product from a company because that company advocated for an important social issue that they cared about (Cone, 2017). Another study found that $88 \%$ of Americans believe firms have the power to effect social change (Global Strategy Group, 2016, p. 2).

6. A Google web search was conducted for news articles and public announcements of companies' endorsements of the boycott. The key words for the search included: "2020 Facebook advertiser boycott" and "stop hate for profit campaign". We also manually collected and reviewed press releases and other public statements from company websites and official social media handles, which were then merged with the Google search results in order to determine the precise date that each announcement was made public for the first time.

7. See $C N N$, "The hard truth about the Facebook ad boycott: Nothing matters but Zuckerberg", 26 June, 2020, available at https:/edition.cnn.com/2020/06/26/tech/facebook-boycott/index.html (accessed on 20
Corporate social advocacy signal 
JCMS

5,1

\section{4}

November, 2020). Also see Pathmatics Blog, "Facebook Advertising Boycott: Political Ad and Free Speech Issues", 29 July, 2020, available at https://www.pathmatics.com/blog/brandsboycottfacebook (accessed on 20 November, 2020).

8. Dodd and Supa (2014) reach a similar conclusion, noting that CSA actions can generate positive perception and goodwill for the corporation and therefore be associated with positive financial performance, as measured by consumer purchase intention.

\section{References}

Afego, P.N. and Alagidede, P. (2021), "CEO statements on racial injustice - do they matter to shareholders?”, Working Paper.

Afego, P.N., Capobianco, P. and Wang, M. (2020), "The economic impacts of ethnic in-group bias: A case study analysis", Working Paper, doi: 10.2139/ssrn.3634111 (accessed 18 November 2020).

Ahern, K.R. and Dittmar, A.K. (2012), "The changing of the boards: the impact on firm valuation of mandated female board representation”, The Quarterly Journal of Economics, Vol. 127 No. 1, pp. 137-197.

Ait-Sahalia, Y., Andritzky, J., Jobst, A., Nowak, S. and Tamirisa, N. (2012), "Market response to policy initiatives during the global financial crisis", Journal of International Economics, Vol. 87 No. 1, pp. 162-177.

Albert, S. and Whetten, D.A. (1985), "Organizational identity", Research in Organizational Behavior, Vol. 7, pp. 263-295.

Amir, E. and Lev, B. (1996), "Value-relevance of nonfinancial information: the wireless communications industry", Journal of Accounting and Economics, Vol. 22 Nos 1-3, pp. 3-30.

Ashforth, B.E. and Mael, F.A. (1996), "Oranizational identity and strategy as a context for the individual", Advances in Strategic Management, Vol. 13, pp. 19-64.

Atanasov, V. and Black, B. (2016), "Shock-based inference in corporate finance and accounting research", Critical Finance Review, Vol. 5, pp. 207-304.

Barnea, A. and Rubin, A. (2010), "Corporate social responsibility as a conflict between shareholders", Journal of Business Ethics, Vol. 97 No. 1, pp. 71-86.

Bash, A. and Alsaifi, K. (2019), "Fear from uncertainty: an event study of Khashoggi and stock market returns", Journal of Behavioral and Experimental Finance, Vol. 23, pp. 54-58.

Bénabou, R. and Tirole, J. (2010), "Individual and corporate social responsibility”, Economica, Vol. 77 No. 305 , pp. 1-19.

Benford, R.D. and Snow, D.A. (2000), "Framing processes and social movements: an overview and assessment”, Annual Review of Sociology, Vol. 26 No. 1, pp. 611-639.

Boehmer, E., Masumeci, J. and Poulsen, A.B. (1991), "Event-study methodology under conditions of event-induced variance", Journal of Financial Economics, Vol. 30 No. 2, pp. 253-272.

Bowen, S.A. (2004), "Expansion of ethics as the tenth generic principle of public relations excellence: a Kantian theory and model for managing ethical issues", Journal of Public Relations Research, Vol. 16 No. 1, pp. 65-92.

Campbell, J.Y., Lo, A.W. and MacKinlay, A.C. (1997), The Econometrics of Financial Markets, Princeton University Press, Princeton, NJ.

Cartabuke, M., Westerman, J.W., Bergman, J.Z., Whitaker, B.G., Westerman, J. and Beekun, R.I. (2019), "Empathy as an antecedent of social justice attitudes and perceptions", Journal of Business Ethics, Vol. 157, pp. 605-615.

Chatterji, A.K. and Toffel, M.W. (2018), "The New CEO Activists. A playbook for polarized political times", Harvard Business Review, Vol. 96 No. 1, pp. 78-89.

Chatterji, A.K. and Toffel, M.W. (2019), "Assessing the impact of CEO activism", Organization and Environment, Vol. 32 No. 2, pp. 159-185. 
Cheng, B., Ioannou, I. and Serafeim, G. (2014), "Corporate social responsibility and access to finance", Strategic Management Journal, Vol. 35 No. 1, pp. 1-23.

Conaway, R.N. and Wardrope, W.J. (2010), "Do their words really matter? Thematic analysis of US and Latin American CEO letters", The Journal of Business Communication, (1973), Vol. 47 No. 2, pp. 141-168.

Cone (2017), "Cone communications CSR study", available at: https://www.conecomm.com/news-blog/ 2017/5/15/americans-willing-to-buy-or-boycott-companies-based-on-corporate-values-accordingto-new-research-by-cone-communications (accessed 25 June 2020).

Cook, A. and Glass, C. (2011), "Leadership change and shareholder value: how markets react to the appointments of women", Human Resource Management, Vol. 50 No. 4, pp. 501-519.

Cook, A. and Glass, C. (2014), "Do diversity reputation signals increase share value?", Human Resource Development Quarterly, Vol. 25 No. 4, pp. 471-491.

Cornelissen, J. (2004), Corporate Communications, Theory and Practice, Sage, London.

Coombs, W.T. and Holladay, S.J. (2018), "Social issue via wicked problems: the role of strategic communication in social issues management", Journal of Communication Management, Vol. 22 No. 1, pp. 79-95.

Cowan, A.R. (1992), "Nonparametric event study tests", Review of Quantitative Finance and Accounting, Vol. 2 No. 4, pp. 343-358.

Crable, R.E. and Vibbert, S.L. (1985), "Managing issues and influencing public policy", Public Relations Review, Vol. 11 No. 2, pp. 3-16.

Creamer, E.G. and Ghoston, M. (2013), "Using a mixed methods content analysis to analyze mission statements from colleges of engineering", Journal of Mixed Methods Research, Vol. 7 No. 2, pp. $110-120$.

Ding, N., Parwada, J.T., Shen, J. and Zhou, S. (2020), "When does a stock boycott work? Evidence from a clinical study of the Sudan divestment campaign”, Journal of Business Ethics, Vol. 163 No. 3, pp. 507-527.

Dodd, M.D. and Supa, D.W. (2014), “Conceptualizing and measuring 'corporate social advocacy' communication: examining the impact on corporate financial performance", Public Relations Journal, Vol. 8 No. 3, pp. 2-23.

Dodd, M.D. and Supa, D. (2015), "Testing the viability of corporate social advocacy as a predictor of purchase intention", Communication Research Reports, Vol. 32 No. 4, pp. 287-293.

Edwards, B. and McCarthy, J.D. (2004), "Strategy matters: the contingent value of social capital in the survival of local social movement organizations", Social Forces, Vol. 83 No. 2, pp. 621-651.

Eilert, M. and Nappier Cherup, A. (2020), "The activist company: examining a company's Pursuit of societal change through corporate activism using an institutional theoretical lens", Journal of Public Policy and Marketing, Vol. 39 No. 4, pp. 461-476.

Ferrell, A., Liang, H. and Renneboog, L. (2016), "Socially responsible firms", Journal of Financial Economics, Vol. 122 No. 3, pp. 585-606.

Freeman, R.E. (1984), Strategic Management: A Stakeholder Approach, Pitman Publishing, Boston.

Freeman, R.E., Freeman, R.E., Pierce, J. and Dodd, R. (2000), Environmentalism and the New Logic of Business: How Firms can be Profitable and Leave our Children a Living Planet, Oxford University Press.

Friedman, M. (1999), Consumer Boycotts: Effecting Change through the Marketplace and the Media, Routledge, New York.

Global Strategy Group (2016), "Business and politics: do they mix?", available at: www. globalstrategygroup.com/wp-content/uploads/2016/01/GSG-2016-Business-and-Politics-Study_ 1-27-16-002.pdf (accessed 15 June 2020).

Gobe, M. (2001), Emotional Branding, Allworth, New York, NY.
Corporate social advocacy signal 
JCMS 5,1

Gopaldas, A. (2014), "Marketplace sentiments", Journal of Consumer Research, Vol. 41 No. 4, pp. 995-1014.

Hallahan, K. (2001), "The dynamics of issues activation and response: an issues processes model”, Journal of Public Relations Research, Vol. 13 No. 1, pp. 27-59.

Heath, R.L. and Palenchar, M.J. (2009), "Issues management and crisis communication", in Heath, R.L. and Palenchar, M.J., Strategic Issues Management: Organizations and Public Policy Challenges, 2nd ed., Sage Publications, Thousand Oaks, CA, pp. 273-308.

Heilmann, K. (2016), "Does political conflict hurt trade? Evidence from consumer boycotts", Journal of International Economics, Vol. 99, pp. 179-191.

Hillebrand, B., Driessen, P.H. and Koll, O. (2015), "Stakeholder marketing: theoretical foundations and required capabilities", Journal of the Academy of Marketing, Vol. 43 No. 4, pp. 411-428.

Hörisch, J., Freeman, E. and Schaltegger, S. (2014), "Applying stakeholder theory in sustainability management: links, similarities, and a conceptual framework", Organization and Environment, Vol. 27 No. 4, pp. 1-19.

Jones, R. and Murrell, A.J. (2001), "Signaling positive corporate social performance: an event study of family-friendly firms", Business and Society, Vol. 40 No. 1, pp. 59-78.

Ju, K., Zhou, D., Zhou, P. and Wu, J. (2014), "Macroeconomic effects of oil price shocks in China: an empirical study based on Hilbert-Huang transform and event study", Applied Energy, Vol. 136, pp. 1053-1066.

King, B.G. (2008), "A political mediation model of corporate response to social movement activism”, Administrative Science Quarterly, Vol. 53 No. 3, pp. 395-421.

King, B. and McDonnell, M.H. (2012), "Good firms, good targets: the relationship between corporate social responsibility, reputation, and activist targeting", in Kiyoteru, T. and Alwyn, L. (Eds), Corporate Social Responsibility in a Globalizing World: Toward Effective Global CSR Frameworks.

King, B.G. and Soule, S.A. (2007), "Social movements as extra-institutional entrepreneurs: the effect of protests on stock price returns", Administrative Science Quarterly, Vol. 52 No. 3, pp. 413-442.

Krippendorff, K. (2004), "Reliability in content analysis: some common misconceptions and recommendations", Human Communication Research, Vol. 30 No. 3, pp. 411-433.

Kılıç, M. and Kuzey, C. (2016), "The effect of board gender diversity on firm performance: evidence from Turkey”, Gender in Management: An International Journal, Vol. 31 No. 7, pp. 434-455.

La Porta, R., Lopez-de-Silanes, F., Shleifer, A. and Vishny, R.W. (2000), "Agency problems and dividend policies around the world", The Journal of Finance, Vol. 55 No. 1, pp. 1-33.

Laskin, A.V. (2016), "Nonfinancial information in investor communications", International Journal of Business Communication, Vol. 53 No. 4, pp. 375-397.

Lenox, M.J. and Eesley, C.E. (2009), "Private environmental activism and the selection and response of firm targets", Journal of Economics and Management Strategy, Vol. 18 No. 1, pp. 45-73.

Lev, B. (2004), "Sharpening the intangibles edge", Harvard Business Review, Vol. 6, pp. 109-116.

Manheim, J.B. (2001), "The death of a thousand cuts", Review-Institute of Public Affairs, Vol. 53 No. 1, pp. 3-6.

Masulis, R.W. and Reza, S.W. (2015), "Agency problems of corporate philanthropy", The Review of Financial Studies, Vol. 28 No. 2, pp. 592-636.

McDonnell, M.H. and King, B. (2013), "Keeping up appearances: reputational threat and impression management after social movement boycotts", Administrative Science Quarterly, Vol. 58 No. 3, pp. 387-419.

Mikeska, J. and Harvey, E.J. (2015), "The political CEO: an event study comparing consumer attributions of CEO behavior", Social Science Quarterly, Vol. 96 No. 1, pp. 76-92. 
Molina-Azorin, J.F., Bergh, D.D., Corley, K.G. and Ketchen, D.J. Jr (2017), "Mixed methods in the organizational sciences: taking stock and moving forward", Organizational Research Methods, Vol. 20 No. 2, pp. 179-192.

Otchere, I. and Ross, M. (2002), "Do share buy back announcements convey firm-specific or industrywide information?: a test of the undervaluation hypothesis", International Review of Financial Analysis, Vol. 11 No. 4, pp. 511-531.

Parcha, J.M. and Kingsley Westerman, C.Y. (2020), "How corporate social advocacy affects attitude change toward controversial social issues", Management Communication Quarterly, Vol. 34 No. 3, pp. 350-383.

Park, K. and Jiang, H. (2020), "Signaling, verification, and identification: the way corporate social advocacy generates brand loyalty on social media", International Journal of Business Communication, doi: 10.1177/2329488420907121.

Patelli, L. and Pedrini, M. (2014), "Is the optimism in CEO's letters to shareholders sincere? Impression management versus communicative action during the economic crisis", Journal of Busines Ethics, Vol. 124 No. 1, pp. 19-34.

Pollock, T.G. and Rindova, V.P. (2003), "Media legitimation effects in the market for initial public offerings", Academy of Management Journal, Vol. 46 No. 5, pp. 631-642.

Pruitt, S.W. and Friedman, M. (1986), "Determining the effectiveness of consumer boycotts: a stock price analysis of their impact on corporate targets", Journal of Consumer Policy, Vol. 9 No. 4, pp. 375-387.

Ragas, M.W. and Laskin, A.V. (2014), "Mixed-methods: measurement and evaluation among investor relations officers", Corporate Communications: An International Journal, Vol. 19 No. 2, pp. 166-181.

Rawlings, L. (2020), "Facebook advertisers boycott: American civil-rights groups Combat misinformation online", Titan, Risk Analysis and Insights, News, North America, (July 15), available at: https://www.internationalaffairshouse.org/facebook-advertisers-boycott-americancivil-rights-groups-combat-misinformation-online/ (accessed 7 January 2021).

Rhee, E.Y. and Fiss, P.C. (2014), "Framing controversial actions: regulatory focus, source credibility, and stock market reaction to poison pill adoption", Academy of Management Journal, Vol. 57 No. 6, pp. 1734-1758.

Rim, H., Lee, Y. and Yoo, S. (2020), "Polarized public opinion responding to corporate social advocacy: social network analysis of boycotters and advocators", Public Relations Review, Vol. 46 No. 2, 101869.

Shleifer, A. and Vishny, R.W. (1989), "Management entrenchment: the case of manager-specific investments", Journal of Financial Economics, Vol. 25 No. 1, pp. 123-139.

Sommerfeldt, E.J. and Yang, A. (2017), "Relationship networks as strategic issues management: an issue-stage framework of social movement organization network strategies", Public Relations Review, Vol. 43 No. 4, pp. 829-839.

Sorescu, A., Warren, N.L. and Ertekin, L. (2017), "Event study methodology in the marketing literature: an overview", Journal of the Academy of Marketing Science, Vol. 45 No. 2, pp. 186-207.

Spence, M. (1974), "Competitive and optimal responses to signals: an analysis of efficiency and distribution", Journal of Economic Theory, Vol. 7 No. 3, pp. 296-232.

Starr, M.A. (2014), "Qualitative and mixed-methods research in economics: surprising growth, promising future", Journal of Economic Surveys, Vol. 28 No. 2, pp. 238-264.

Tomlin, K.M. (2019), "Assessing the efficacy of consumer boycotts of US target firms: a shareholder wealth analysis", Southern Economic Journal, Vol. 86 No. 2, pp. 503-529.

Walker, J. (2020), "Facebook market value Plummets $\$ 56$ billion as advertisers flee platform", Newsweek, (June 27), available at: https:/www.conecomm.com/news-blog/2017/5/15/americanswilling-to-buy-or-boycott-companies-based-on-corporate-values-according-to-new-research-bycone-communications (accessed 8 January 2021). 
JCMS

5,1

68
Weinzimmer, L.G. and Esken, C.A. (2016), "Risky business: taking a stand on social issues", Business Horizons, Vol. 59 No. 3, pp. 331-337.

Wettstein, F. and Baur, D. (2016), "Why should we care about marriage equality?': political advocacy as a part of corporate responsibility”, Journal of Business Ethics, Vol. 138 No. 2, pp. 199-213.

Whetten, D.A. and Mackey, A. (2002), "A social actor conception of organizational identity and its implications for the study of organizational reputation”, Business and Society, Vol. 41 No. 4, pp. 393-414.

Zajac, E.J. and Westphal, J.D. (2004), "The social construction of market value: institutionalization and learning perspectives on stock market reactions", American Sociological Review, Vol. 69 No. 3, pp. $433-457$.

\section{Corresponding author}

Pyemo N. Afego can be contacted at: u19408723@tuks.co.za

For instructions on how to order reprints of this article, please visit our website: 